\title{
Fibrin thrombi, a cause of clindamycin-associated colitis?
}

\author{
W. V. BOGOMOLETZ \\ From the Department of Pathology, Queen Mary's Hospital, London
}

SUMMARY Rectal biopsies from five patients with clindamycin-associated colitis were studied with the intention of identifying fibrin thrombi in capillaries. Capillary thrombosis was present in all five cases, three with pseudomembranous colitis and two with non-specific colitis. The significance of capillary thrombosis and its relationship to other ischaemic lesions of the gut are discussed.

An increasing number of cases have been recently reported of colitis in patients treated with the antibiotic clindamycin. The clinical, radiological, and endoscopic features of clindamycin-associated colitis are now well documented (Shimkin and Link, 1973; Viteri et al., 1974; Le Frock et al., 1975). Biopsy may show one of two histological patterns: a typical pseudomembranous colitis or a non-specific colitis. In clindamycin-associated colitis, the pseudomembranous type has received more attention, probably because of its more dramatic pathological and clinical complications.

Various attempts have been made to identify a specific cause for pseudomembranous colitis associated with clindamycin therapy. One of the problems is that pseudomembranous colitis has been described after treatment with a variety of antibiotics other than clindamycin, such as tetracycline, chloramphenicol, ampicillin, penicillin, and cephalosporin. Furthermore, with lesions involving large and small bowel, pseudomembranous enterocolitis is also known to occur as a complication of the postoperative state, bowel obstruction, reticuloses, chronic renal and cardiac diseases, staphylococcal overgrowth, and heavy metal poisoning.

Ten years ago, pseudomembranous enterocolitis (Goulston and McGovern, 1965) and ischaemic enterocolitis (McGovern and Goulston, 1965; Marston et al., 1966) were looked upon as two different pathological entities. Later, it was suggested that pseudomembranous enterocolitis was also and primarily of ischaemic nature, with or without superimposed secondary bacterial infection (Morson and Dawson, 1972; Morson, 1974). A theory thus emerged that both these conditions represented

Received for publication 3 March 1976 different stages or different levels of deprivation of the blood supply to the bowel mucosa.

In 1971, fibrin thrombi were described in the microcirculation of intestinal mucosa and submucosa, in two series of necropsy material (Margaretten and McKay, 1971; Whitehead, 1971) which included cases referred to collectively as ischaemic and pseudomembranous enterocolitis. The pattern and distribution of these fibrin thrombi in capillaries appeared to parallel that seen in experimentally-induced intravascular coagulation (McKay et al., 1971) in the gastrointestinal tract.

The present study was undertaken to verify the presence of fibrin thrombi in rectal biopsies of five patients with clindamycin-associated colitis.

\section{Methods}

Rectal biopsies were examined from five patients who developed diarrhoea while being treated with clindamycin. The rectal biopsies were paraffinembedded, cut at 10 levels, and multiple sections stained by haematoxylin-eosin, Alcian Green-Van Gieson, Gram and Lendrum MSB methods. All the sections were particularly examined for the presence of fibrin thrombi in capillaries of the mucosa and submucosa. As a control, similarly processed and stained sections were examined from nine rectal biopsies reported as 'within normal limits'-that is, from patients showing no histological evidence of colitis and not receiving clindamycin or any other antibiotic at the time of the biopsy.

The relevant clinical data of the five patients included in this study are summarized in the Table.

In all five patients, the bowel symptoms improved dramatically after withdrawal of clindamycin. Four patients (cases 1, 2, 4, and 5) were eventually dis- 


\begin{tabular}{|c|c|c|c|c|c|c|c|c|}
\hline \multirow[t]{2}{*}{$\begin{array}{l}\text { Case no., } \\
\text { age/sex }\end{array}$} & \multicolumn{2}{|c|}{$\begin{array}{l}\text { Oral } \\
\text { clindamycin }\end{array}$} & \multirow{2}{*}{$\begin{array}{l}\text { Reasons for } \\
\text { antibiotic } \\
\text { therapy }\end{array}$} & \multirow[t]{2}{*}{ Bowel symptoms } & \multirow[t]{2}{*}{$\begin{array}{l}\text { Initial } \\
\text { proctoscopy }\end{array}$} & \multirow[t]{2}{*}{ Barium enema } & \multirow[t]{2}{*}{ Haematology } & \multirow[t]{2}{*}{ Bacteriology } \\
\hline & $\begin{array}{l}\text { Dose } \\
\text { (mg/day) }\end{array}$ & Days & & & & & & \\
\hline${ }_{50 / M}^{1}$ & 600 & 6 & $\begin{array}{l}\text { Post-operative } \\
\text { infection (limb } \\
\text { amputation for } \\
\text { arterial } \\
\text { disease) }\end{array}$ & $\begin{array}{l}\text { Diarrhoea }+ \\
\text { mucus. } \\
\text { Abdominal pain } \\
\text { and tenderness }\end{array}$ & $\begin{array}{l}\text { Ulcerations and } \\
\text { 'cobblestone' } \\
\text { pattern }\end{array}$ & $\begin{array}{l}\text { Severe and total } \\
\text { colitis }\end{array}$ & $\begin{array}{l}\text { Platelets: normal } \\
\text { numbers on } \\
\text { blood film }\end{array}$ & $\begin{array}{l}\text { Normal faecal } \\
\text { flora }\end{array}$ \\
\hline $\begin{array}{l}2 \\
64 / M\end{array}$ & 600 & $\begin{array}{l}\text { Sev- } \\
\text { eral }\end{array}$ & $\begin{array}{l}\text { Chronic } \\
\text { bronchitis }\end{array}$ & $\begin{array}{l}\text { Diarrhoea + } \\
\text { blood }\end{array}$ & Inflamed mucosa & $\begin{array}{l}\text { Within normal } \\
\text { limits }\end{array}$ & $\begin{array}{l}\text { Platelets: } \\
\text { normal numbers } \\
\text { on blood film }\end{array}$ & 0 \\
\hline $\begin{array}{l}3 \\
71 / M\end{array}$ & 600 & 13 & $\begin{array}{l}\text { Diabetes and } \\
\text { gangrene of foot }\end{array}$ & $\begin{array}{l}\text { Diarrhoea. } \\
\text { Abdominal } \\
\text { distension }\end{array}$ & Friable mucosa & 0 & $\begin{array}{l}\text { Prothrembin } \\
\text { raised. } \\
\text { Platelets: normal } \\
\text { numbers on } \\
\text { blood film }\end{array}$ & $\begin{array}{l}\text { Normal faecal } \\
\text { flora }\end{array}$ \\
\hline $\begin{array}{l}4 \\
50 / F\end{array}$ & 900 & 12 & $\begin{array}{l}\text { Postoperative } \\
\text { infection (oral } \\
\text { surgery) }\end{array}$ & $\begin{array}{l}\text { Diarrhoea }+ \\
\text { mucus }+ \\
\text { blood }\end{array}$ & $\begin{array}{l}\text { Friable and } \\
\text { granular mucosa } \\
+ \text { few ulcers }\end{array}$ & 0 & $\begin{array}{l}\text { Platelets: normal } \\
\text { numbers on } \\
\text { blood film }\end{array}$ & $\begin{array}{l}\text { Normal faecal } \\
\text { flora }\end{array}$ \\
\hline $\begin{array}{l}5 \\
73 / M\end{array}$ & 600 & 2 & $\begin{array}{l}\text { Deep-vein } \\
\text { thrombosis + } \\
\text { arterial disease. } \\
\text { Postoperative } \\
\text { infection (limb } \\
\text { amputation) }\end{array}$ & $\begin{array}{l}\text { Diarrhoea + } \\
\text { blood }\end{array}$ & Inflamed mucosa & 0 & $\begin{array}{l}\text { Clotting } \\
\text { screening for } \\
\text { deep-vein } \\
\text { thrombosis, } \\
\text { treated with } \\
\text { Streptokinase } \\
\text { and Heparin }\end{array}$ & 0 \\
\hline
\end{tabular}

Table Clinical summary of five cases of clindamycin-associated colitis

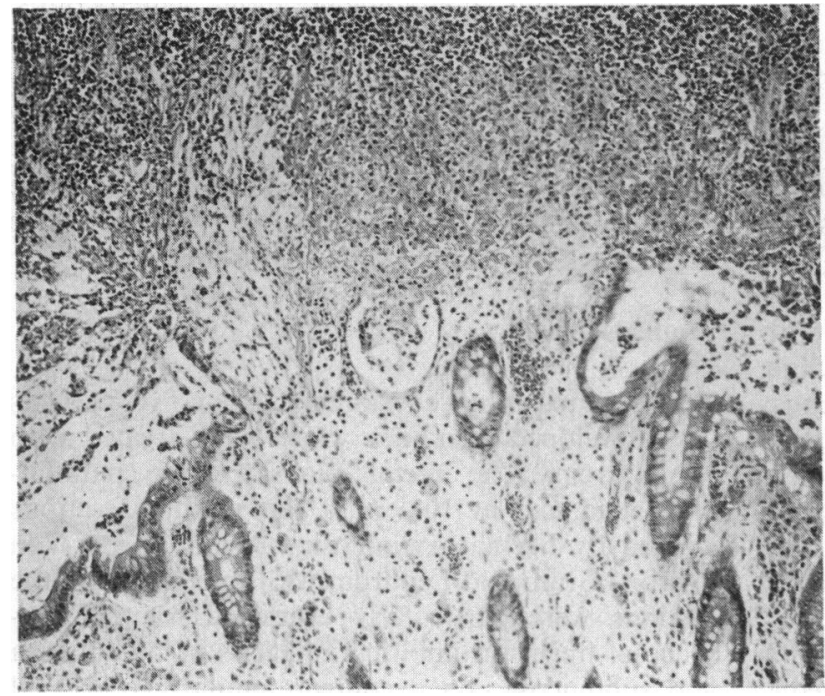

Fig. 1 Pseudomembranous colitis. Typical lesion of focal necrosis of the mucosa with attached pseudomembrane, producing a picture like $a$ 'volcanic eruption'. $H$ and $E \times$ 100.

charged from hospital. One patient (case 3) died 20 days after his episode of colitis; postmortem examination showed myocardial infarction as a cause of death but no identifiable lesions in the large bowel.

\section{Results}

Histological examination of the various sections from the five rectal biopsies showed two distinct types of colitis:

1. Pseudomembranous colitis was observed in three cases (nos. 1, 2, and 3). There were typical pseudomembranes composed of pus, fibrin, and mucus, overlying groups of distended and partially necrotic glands, some of which contained mucus plugs. The corresponding surface epithelium had 


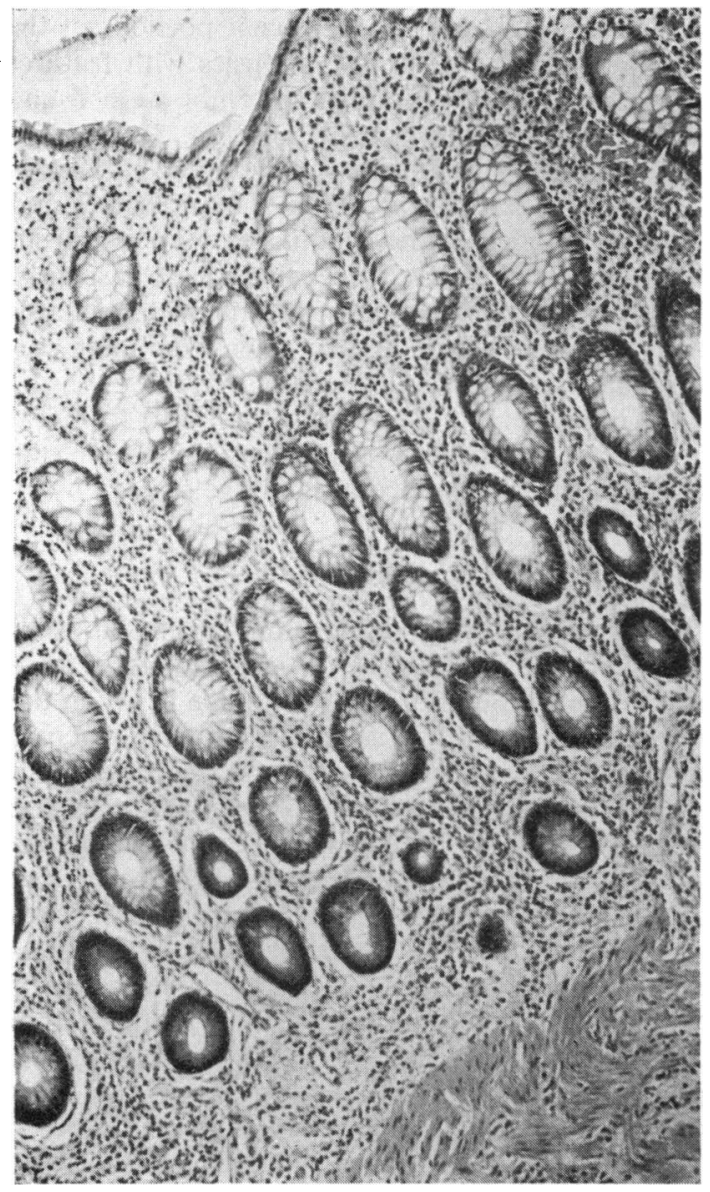

sloughed away. The lamina propria contained acute and chronic inflammatory cells of all types, the intensity of this infiltrate varying from mild to severe according to the proximity of the pseudomembranous lesions. The lamina propria also showed some oedema (Fig. 1).

In the mucosa adjacent to the pseudomembranous lesions, the inflammatory infiltrate in the lamina propria was less marked. The glands showed either a fairly normal goblet cell population or a hyperplastic epithelium with depletion of mucus content. Some of the glands situated nearer to the pseudomembranous lesions contained an excess of mucus.

The underlying muscularis mucosae and submucosa were somewhat dissociated by oedema and contained scattered inflammatory cells of all types.

2. Non-specific colitis (colitis defined as without pseudomembranes and without mucosal necrosis) was seen in two cases (nos. 4 and 5). The superficial epithelium showed mild and patchy degenerative changes without erosion. The lamina propria contained a moderate excess of inflammatory cells with varying numbers of plasma cells, lymphocytes, and polymorphonuclears. Glands showed minimal changes in mucus content. A few glands had a hyperplastic epithelium with neutrophil infiltration but no true 'crypt abscess' formation (Fig. 2).

Fig. 2 Non-specific colitis showing moderate but diffuse excess of inflammatory cells in the mucosal lamina propria. The goblet cell population is well preserved in the superficial glands but mucus content is decreased in the deeper glands. $H$ and $E \times 100$.

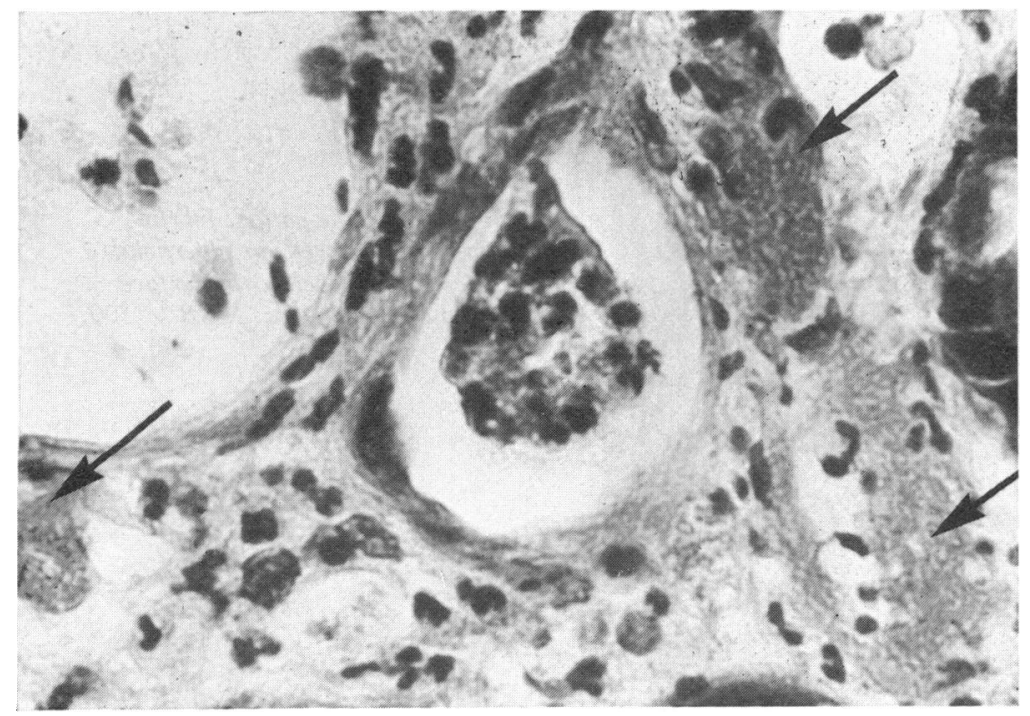

Fig. 3 Pseudomembranous colitis. Fibrin microthrombi (arrowed) in mucosal capillaries, adjacent to a pseudomembranous lesion. MSB $\times 400$. 
3. Fibrin microthrombi were identified in capillaries in all five biopsies. In the three biopsies showing pseudomembranous colitis, fibrin thrombi were seen, at random, in capillaries lying directly below the pseudomembranes (Fig. 3) and in capillaries

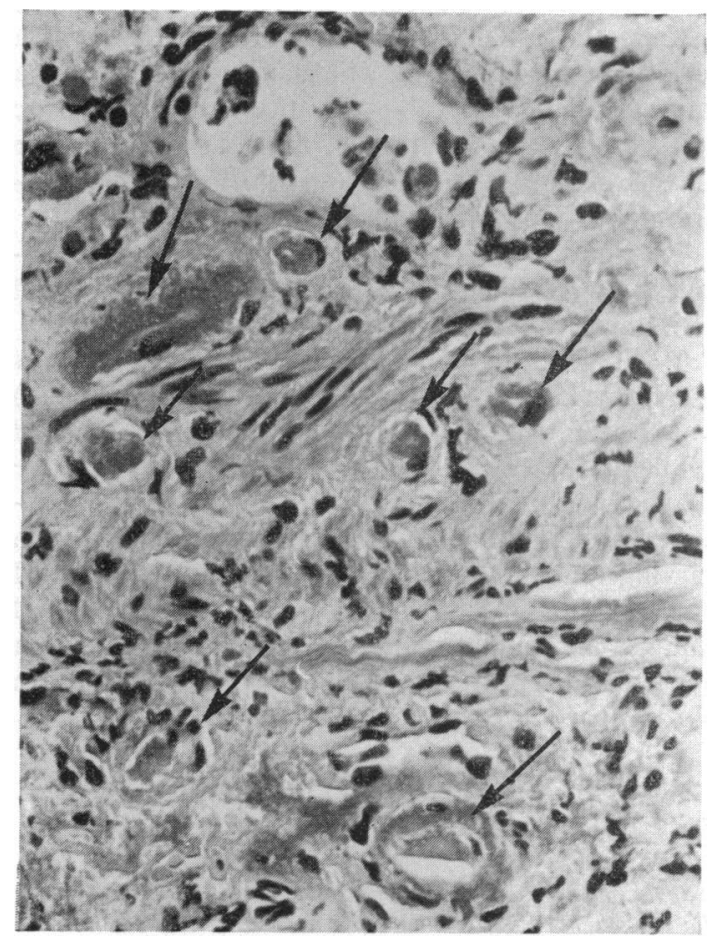

Fig. 4 Pseudomembranous colitis. Fibrin microthrombi (arrowed) in capillaries situated on either side of the muscularis mucosae. $M S B \times 300$. situated in the deeper and adjacent portions of the mucosa (Fig. 4). In the two biopsies with features of non-specific colitis, fibrin thrombi were found only in the superficial capillaries (Fig. 5). In addition to fibrin thrombosis, many other capillaries showed only severe congestion. The arterioles and venules identified in the submucosa were free from thrombosis and showed no evidence of vasculitis. The identification of capillary thrombi with Lendrum MSB was more effective than when examining sections stained with haematoxylin-eosin.

4. Gram staining of the sections failed to reveal any bacteria either on the surface or within the tissues of the rectal mucosa in all five cases.

\section{Discussion}

The majority of recent publications on clindamycinassociated colitis (large series and individual case reports) give little information or none at all on the presence or absence of fibrin thrombi in mucosal capillaries of rectal biopsies. Several reports contain no mention of the condition of the capillaries (Le Frock et al., 1975; Price and Davies, 1975; Burbige and Milligan, 1975; Tedesco et al., 1974; Tedesco et al., 1975). Furthermore, Tedesco and his associates who have a wide experience of clindamycin-associated colitis, specifically mention the absence of thrombosis in mucosal vessels in one of their large series (Sumner and Tedesco, 1975) but the use of a specific stain for fibrin is not apparent from their paper.

On the other hand, Butsch (1975) described vasculitis and capillary thrombosis in the submucosa in his case report of one patient. According to Steer (1975), electron microscopy showed fibrin within the

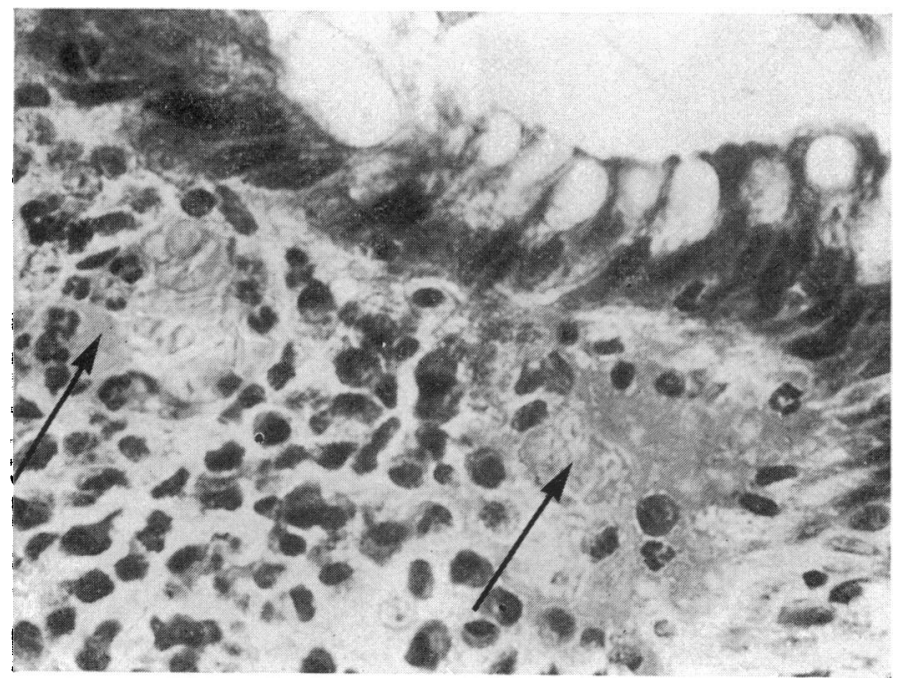

Fig. 5 Non-specific colitis. Fibrin microthrombi (arrowed) in superficial capillaries situated below the surface epithelium of the mucosa. MSB $\times 300$. 
vessels, at the site of ulceration, in four cases of clindamycin-associated pseudomembranous colitis.

Our own findings indicate that fibrin thrombi in capillaries are probably more common in rectal biopsies from cases of clindamycin-associated colitis than would appear from the literature, but a special stain for fibrin must be used. The presence of these capillary thrombi is in accordance with similar findings in ischaemic lesions of the gut, reported before the wider use of clindamycin and the awareness of clindamycin-associated colitis.

Furthermore, in our series, capillaries containing fibrin thrombi have been identified, regardless of the histological type of colitis: pseudomembranous or non-specific. Non-specific colitis probably represents an early stage or a forme frustre of the more full blown picture of pseudomembranous colitis. It is also possible that capillary thrombosis could produce either the patchy necrosis of pseudomembranous lesions or a more non-specific inflammatory reaction, according to the level of capillary involvement in the mucosa and submucosa-that is, superficial or deep.

In previous studies (Margaretten and McKay, 1971; Whitehead, 1971), the cause of disseminated fibrin thrombi in intestinal mucosa has been attributed to an episode of localized or generalized intravascular coagulation. The findings of capillary thrombosis suggest that a similar defect in the clotting mechanism may be responsible for the colitis after clindamycin therapy.

The relationship of clindamycin itself to capillary thrombosis in the bowel mucosa is difficult to ascertain. As other antibiotics are known to be associated with pseudomembranous colitis, it may well be that the type of antibiotic is irrelevant. Furthermore, it is possible that capillary thrombosis is the initial cause of the colitis and that clindamycin has only, if any, a secondary effect on an already damaged and ischaemic mucosa.

\section{References}

Burbige, E. J., and Milligan, F. D. (1975). Pseudomembranous colitis: association with antibiotics and therapy with cholestyramine. Journal of the American Medical Association, 231, 1157-1158.

Butsch, J. L., Al-Humadi, A. H., and Alford, J. E. (1975). Clindamycin colitis following clindamycin therapy. Diseases of the Colon and Rectum, 18, 152-157.

Goulston, S. J. M., and McGovern, V. J. (1965). Pseudomembranous colitis. Gut, 6, 207-212.

Le Frock, J. L., Klainer, A. S., Chen, S., Gainer, R. B., Omar, M., and Anderson, W. (1975). The spectrum of colitis associated with lincomycin and clindamycin therapy. Journal of Infectious Diseases, 131, suppl. 108-115.

McGovern, V. J., and Goulston, S. J. M. (1965). Ischaemic enterocolitis. Gut, 6, 213-220.

McKay, D. G., Linder, M. M., and Cruse, V. K. (1971). Mechanisms of thrombosis of the microcirculation. American Journal of Pathology, 63, 231-241.

Margaretten, W., and McKay, D. G. (1971). Thrombotic ulcerations of the gastrointestinal tract. Archives of Internal Medicine, 127, 250-253.

Marston, A., Pheils, M. T., Thomas, M. L., and Morson, B. C. (1966). Ischaemic colitis. Gut, 7, 1-15.

Morson, B. C. (1974). The technique and interpretation of rectal biopsies in inflammatory bowel disease. Pathology Annual, 9, 209-230.

Morson, B. C., and Dawson, I. M. P. (1972). Gastrointestinal Pathology, pp. 259. Blackwell: Oxford.

Price, A. B., and Davies, D. R. (1975). The diagnosis of pseudomembranous colitis by rectal biopsy. Proceedings of the Royal Society of Medicine, 68, 31.

Shimkin, P. M., and Link, R. J. (1973). Pseudomembranous colitis: a consideration in the barium enema differential diagnosis of acute generalized ulcerative colitis. British Journal of Radiology, 46, 437-439.

Steer, H. W. (1975). The pseudomembranous colitis associated with clindamycin therapy-a viral colitis. Gut, 16, 695-706.

Sumner, H. W. and Tedesco, F. J. (1975). Rectal biopsy in clindamycin-associated colitis. Archives of Pathology, 99, 237-241.

Tedesco, F. J., Anderson, C. B., and Ballinger, W. F. (1975.) Drug-induced colitis mimicking an acute surgical condition of the abdomen. Archives of Surgery, 110, 481-483.

Tedesco, F. J., Barton, R. W., and Alpers, D. H. (1974). Clindamycin-associated colitis: a prospective study. Annals of Internal Medicine, 81, 429-433.

Viteri, A. L., Howard, P. H., and Dyck, W. P. (1974). The spectrum of lincomycin-clindamycin colitis. Gastroenterology, 66, 1137-1144.

Whitehead, R. (1971). Ischaemic enterocolitis: an expression of the intravascular coagulation syndrome. Gut, 12, 912917. 